\title{
Prophylactic Effects of Turmeric against Bovine Mastitis
}

\author{
N. Sahoo ${ }^{*}$, P. Sahoo ${ }^{1}$, N.C. Behura ${ }^{2}$ and S. Biswal ${ }^{1}$ \\ ${ }^{1}$ Department of Epidemiology and Preventive Medicine, ${ }^{2}$ Department of Animal Nutrition, \\ College of Veterinary Science and Animal Husbandry, Odisha University of Agriculture and \\ Technology, Bhubaneswar-751003, India \\ *Corresponding author
}

\begin{tabular}{l} 
K e y w o r d s \\
$\begin{array}{l}\text { Prophylactic } \\
\text { effects, Turmeric, } \\
\text { Bovine mastitis }\end{array}$ \\
\hline Article Info \\
$\begin{array}{l}\text { Accepted: } \\
\text { 20 June } 2020 \\
\text { Available Online: } \\
\text { 10 July } 2020\end{array}$ \\
\hline
\end{tabular}

\section{A B S T R A C T}

Bovine mastitis contributed significantly towards antimicrobial resistance. A farmers' participatory field trial was conducted in 100 cows of 12 dairy farms clustered in a locality of Bhubaneswar smart city, Odisha to study the preventive effect of turmeric. Cross-bred Jersey cows with 8 to $10 \mathrm{~L}$ milk yield per day, between $2^{\text {nd }}$ to $5^{\text {th }}$ lactation and one $1-2$ months old calves at foot without any signs of disease/ disorder including mastitis were the criteria of selection. History, clinical examination, modified California mastitis test, microbiological examination and molecular tests were employed to ascertain type of mammary infection. Cows with teat dip in $5.0 \%$ turmeric aqueous solution for five minutes after each milking upto 90 days suffered from mastitis to a tune of $8.1 \%$ as against $50.0 \%$ in untreated cows. Results unfolded a simplest way of preventing mastitis in cows.

\section{Introduction}

Bovine mastitis exerts high economic losses to the dairy industry across the globe. Antibiotics, selected either by empirical means or in vitro antimicrobial sensitivity test, are commonly prescribed for therapeutic and prophylactic purposes. However, such practices are not free from health hazards. The issues relating antibiotic residues in milk as well as antimicrobial resistance have become areas of concern. Under such circumstances, use of herbal preparations is gaining importance as an alternative to antibiotic approach. Different plant species have been documented for the control of mastitis in bovines (1). Traditional healers use a number of plants against this ailment. The plant species recorded against mammary gland infection are Capsicum annuum, Lepidium sativum, Allium sativum, Sesamum indicum, Curcuma longa, Citrus limon, Zingiber officinale, Citrullus colocynthis, Cuminum cyminum, Rosa indica, 
Centratherum anthelmisticum, Triticum aestivum, Nigella sativa and Peganum harmala. Present study deals with a farmers' participatory field-based study on prevention of mastitis in cows using turmeric solution.

\section{Materials and Methods}

Twelve private dairy farms clustered in a particular locality of Bhubaneswar smart city, Odisha (Coordinate: $20.2573^{\circ} \mathrm{N}, 85.8467^{\circ} \mathrm{E}$ ) were selected for the study. All the farms were under similar management practices especially with respect to housing, feeding and sanitation. Cows were hand-milked by the owner twice a day and the calves were not allowed to suckle after milking. Owners of the dairy farms, when explained about the plan of work and its possible benefit, agreed to participate in the field study.

The study period covered September 2019 to January, 2020. Apparently healthy cross-bred Jersey cow with 8 to $10 \mathrm{~L}$ milk yield per day, $2^{\text {nd }}$ to $5^{\text {th }}$ lactation and one 1-2 months old calf at foot were the criteria for selection. Cows without the sign(s) of disease and/or disorder including mastitis as revealed from history and clinical examination were subjected to further screening with modified california mastitis test (MCMT) followed by microbiological examination.

Milk sample from individual cow was initially tested by MCMT as per the standard procedure (2). About 20 milliliter of milk sample was pooled from all functional quarters in a dry clean container. MCMT reagent was prepared with $3 \%$ solution of sodium lauryl sulphate in distill water and indicator bromocresol purple. Equal amount of MCMT reagent and milk sample was taken on the paddle and mixed in a swirling manner. Results were read within 15 seconds. Milk samples showing negative results were further subjected to bacteriological investigation.
Approximately 2.0 milliliter of milk sample was collected aseptically in sterile vial.Milk sample was inoculated into nutrient broth and incubated at $37^{\circ} \mathrm{C}$. After 24 hours of incubation streaking was done in nutrient agar and incubated aerobically at $37{ }^{\circ} \mathrm{C}$ for 24 hours. Gram staining of colonies in agar plate was performed to ascertain the morphological features. Cows with absence of bacterial growth in agar plate were considered negative for mastitis and included for investigation.

One hundred apparently healthy cows fulfilling above criteria were randomly divided into two equal groups (Gr I to II). Cows of Gr I were subjected to teat dipping with $5 \%$ turmeric solution after each milking whereas cows of Gr II were taken as untreated control.

Owners were advised to collect/procure turmeric (dry root of Curcuma longa) from the local market. It was powdered and stored in room temperature for future use. After each milking, all the functional teats of a cow were dipped in freshly prepared $5.0 \%$ aqueous solution (drinking water) of turmeric for 5 minutes. Such practice was continued for 90 days. Farmers were educated to record and inform the abnormality in milk, gland or cow so as to initiate the investigation process on history, clinical examination, MCMT and microbiological examination. Cows with presence of pathogen in milk sample but absence of physical abnormities in milk and clinical changes in gland and/or cow were classified as subclinical mastitis whereas cows with visible abnormalities in milk and/or gland were designated as clinical mastitis. In positive cases identification of bacterial pathogen was undertaken through molecular test. DNA extracted from pure bacterial colonies was subjected to polymerase chain reaction using universal $16 \mathrm{~S}$ primers followed by Sangers sequencing. 


\section{Results and Discussion}

Out of 100 apparently healthy cows free from mammary gland infection included in the study, 49 cows from Gr I and 48 cows from Gr II competed the total period of 90 days, of which $03(8.1 \%)$ and $24(50.0 \%)$ cows suffered from mastitis, respectively (Table). Observation revealed that the number of cows with clinical and subclinical mastitis in Gr I were 0 and 03 as against 02 and 22 in Gr II, respectively. In other word post milking teat dip with $5 \%$ turmeric solution significantly reduced $(\mathrm{P} \leq 0.5)$ occurrence of mastitis in cows of Group I. The pathogens identified through molecular test were Staphylococcus aureus, Streptococcus uberis, Streptococcus agalactiae, Streptococcus dysagalactiae, Escherichia coli and Klebsiella pneumoniae. There was no change in the colour, odour and flavor of the milk treated with turmeric solution that eliminated any undesirable effects on acceptance of the milk by the consumers. The remaining 03 cows i.e., 01 from Gr I and 02 from Gr II were excluded from calculation as they developed illness other than mastitis.

A significant reduction of SCC and total bacterial count was observed in mastitic buffalo cows treated with hydro-methanolic extract of $C$. longa through intramammary route (3). They opined that and C. longa possesses antibacterial, antiinflammatory and immunomodulatory properties. Significant antibacterial activity of raw extract of $C$. longa was recorded against bovine mastitis causing bacteria especially the Streptococcus and Staphylococcus species (4). It is also relevant to mention here the observation made by earlier workers (5) who indicated safe administration of topical curcumin in breast feeding women suffering from lactationalmammitis. Post-milking herbal teat dip 'Mastidip Liquid' (Supplied by M/S Ayurvet Limited, Baddi, H.P., India) comprising of herbs viz, Berberis lycium, Curcuma longa, Eucalyptus globulus, Azadirachta indica is an effective management strategy to reduce the new intramammary infection rate in dairy cows (6). Similar types of beneficial effects have also been documented with the use of Mastilep Gel (7).

The practice of ethnoveterinary medicine is regarded as a sustainable alternative to synthetic medicine and that branch of health science is gaining momentum now. Herbal products are considered safe, cheap and devoid of undesirable side effects. According to the World Health Organization, medicinal plants would be the best source to obtain a variety of drugs and active compounds. Therefore, plants indigenous to any region are being investigated locally to explore their possibility for medicinal use. Turmeric, an easily available herbal product of Curcuma longa, was selected and subjected to study its effects on prevention of mastitis in cows.

The plant Curcuma longa belongs to the family Zingiberaceae. Components of turmeric are named curcuminoids, which include mainly curcumin (diferuloyl methane), demethoxycurcumin, and bisdemethoxycurcumin (8). Of these, curcumin is the most important fraction responsible for the biological activities of turmeric. It possesses antibacterial and antifungal effects, besides other properties like antioxidant, anti-inflammatory, anti-platelet, anticancerous (9). A significant reduction in $S$. aureus count was observed by earlier worker in cottage cheese samples treated with 2.0 to 6.0 per cent of powdered turmeric (10). Turmeric at a concentration between 1 to 5 per cent inhibited bacterial growth (11). Antimicrobial activity of curcumin against various pathogens like Bacillus subtilis, Klebsiella pneumonia, Escherichia coli, Enterobacter aerogenes, Pseudomonas 
aeruginosa, Staphylococcus aureus and Proteus mirabilis has been reported earlier (12). The above statement supports the concentration of turmeric $(5.0 \%)$ used in the trial.

Table.1 Effects of 5\% turmeric solution teat dip on prevention of mastitis in cows

\begin{tabular}{|l|c|c|c|c|}
\hline \multirow{2}{*}{ Group } & \multicolumn{2}{|c|}{$\begin{array}{c}\text { No. of } \\
\text { healthy } \\
\text { lactating } \\
\text { cows }\end{array}$} & \multicolumn{2}{|c|}{$\begin{array}{c}\text { No. of lactating cows suffered from } \\
\text { mastitis during 90 days of observation }\end{array}$} \\
\cline { 2 - 5 } & Clinical & Subclinical & Total \\
\hline Group I (Turmeric solution) & 49 & 0 & 03 & $4(8.1 \%)^{*}$ \\
\hline Group II (Untreated control) & 48 & 2 & 22 & $2450.0 \%)$ \\
\hline
\end{tabular}

It is worth to ink here that the practice of teat dips with 5 per cent solution of the turmeric solution after each milking exerted significant prophylactic effect and curtailed udder infections. Further studies with respect to its concentration, dose and duration would help to popularize the potentiality of turmeric in a more simplified way in control of mastitis.

\section{Acknowledgment}

Authors are thankful to the dairy farm owners for their sincere cooperation during the entire period of field investigation.

\section{References}

1. Dilshad, S. M. R., Rehman, N. U., Ahmad, N. and Iqbal, A. 2010. Documentation of ethnoveterinary practices for mastitis in dairy animals in Pakistan. Pakistan Veterinary Journal, 30(3): 167-171.

2. Schlam, O.W. and Noorland, D.O. 1957. Experiments and observations leading to the development of California mastitis test. Journal of American Veterinary Medical Association, 130: 199-204.

3. Mukherjee, R., Jadhav, R. K., Sharma, N., Sahu, B. D. and De, U. K. 2014. Milk leukocyte adhesion molecules in response to Curcuma longa plus $\alpha$ tocopherol and selenium in mastitic Riverine buffaloes. Buffalo Bulletin, 33 (2): 215-220.

4. Bhatt, V. D., Pandya, B. B., Joshi, C. G. and Kunjadia, A. P. 2013. Curcuma longa: An alternative to antibiotics to combat mastits in cattle. Wayamba Journal of Animal Science, 578X: 582589.

5. Afshariani, R., Farhadi, P., Ghaffarpasand, F. and Roozbeh, J. 2014. Effectiveness of topical curcumin for treatment of mastitis in breastfeeding women: A randomized, double-blind, placebo-controlled clinical trial. Oman Medical Journal, 29: 330-334.

6. Ramprabhu, R., Jairam, Karthik, A., Ravikanth, K., Maini, S. and Adarsh. 2014. Evaluation of regular teat sanitization control measures for prevention of subclinical mastitis in cattle. American Journal of Phytomedicine and Clinical Therapeutics, 2(10): 1212-1216.

7. Ranaut, N. S., Gupta, S., Adarsh, Maini, S. and Ravikanth, K. 2015. Efficacy evaluation AV/AMP/34, mastilep gel, herbal spray (AV/AMS/15) in sub 
clinical mastitis in bovines. International journal of pharmaceutical research and bio-science, 4(3): 154-159.

8. Chainani-Wu, N. 2003. Safety and antiinflammatory activity of curcumin: a component of turmeric (Curcuma longa). Journal of Alternative and Complementary Medicine, 9(1): 161-8.

9. Luthra, P. M., Singh, R. and Chandra, R. 2001. Therapeutic uses of Curcuma longa (Turmeric). Indian Journal of Clinical Biochemistry, 16(2): 153-160.

10. Ferreira, A. C. 2003. Use of turmeric (Curcuma longa) in the reduction
Staphylococcus aureus ATCC 12600 in ricotta. Lavras: UFLA.75p.

11. Shelef, L. A., Naglik, O. A. and Bogen, D. W. 1980. Sensitivity of some common food-borne bacteria to the spices sage, rosemary and allspice. Journal of Food Science, 45(4): 10421044.

12. Singh, R. P. and Jain, D. A. 2012. Evaluation of antimicrobial activity of curcuminoids isolated from turmeric. International Journal of Pharmacy \& Life Science, 3(1): 1368-1376.

\section{How to cite this article:}

Sahoo, N., P. Sahoo, N.C. Behura and Biswal, S. 2020. Prophylactic Effects of Turmeric against Bovine Mastitis. Int.J.Curr.Microbiol.App.Sci. 9(07): 4080-4084.

doi: https://doi.org/10.20546/ijcmas.2020.907.479 